\title{
Petroleum-geological activities in 1993: oil source rocks the dominant theme of the season's field programme
}

\author{
Flemming G. Christiansen and T. C. R. Pulvertaft
}

After three years with a high level of activity in Greenland, both onshore and offshore, the scope of petroleumrelated field activities in 1993 was relatively restricted. No seismic acquisition was carried out either by GGU or by the KANUMAS group of companies, but onshore there was activity in both West and East Greenland, mainly concerned in one way or other with oil source rocks and factors governing their distribution and potential.

In West Greenland the live oil showing discovered in 1992 in vesicular basalts at Marraat, Nuussuaq peninsula, was revisited and the extent of the showing in surface outcrops was mapped (Christiansen et al., this report). It was found that in an area about a kilometre along strike and several hundred metres across strike, virtually all porosity in the vesicular parts of the exposed lavas is plugged by bitumen. After mapping and surface sampling had been completed, GGU was fortunate in being able to take over a drilling rig that had just completed a drilling programme for a mining company working in the area, and in August a well was drilled near the site of the original discovery. The core recovered confirmed that the vesicular parts of the basalt flows down to a depth of $90 \mathrm{~m}$ contain liquid oil (Fig. 1). Below this the basalts have very poor porosity and permeability, and show only very sparse traces of oil.

Because of technical problems, drilling had to be terminated at a depth of $446.85 \mathrm{~m}$, before the base of the basalts had been penetrated. From the geology of the surrounding area, it is expected that the basalts are underlain by a sedimentary succession of latest Maastrichtian to Early Paleocene age (Nøhr-Hansen, 1993a) which consists of marine slope mudstones interlayered with thick, porous turbiditic channel sandstones (Dam \& Sønderholm, in press).

After completion of drilling, a valve was mounted at the top of the casing. In late October the well was revisited and the hole logged using a standard spectrum of tools. A geochemical analytical programme involving organic geochemistry of oil and gas and chemistry of water is being carried out with a view to characterising the fluids and interpreting the nature of the source rock (Christiansen et al., this report).

The results obtained to date on the Marraat oil showing demonstrate that a source rock capable of generating oil exists in West Greenland. Further work, including renewed drilling, is needed to find this source rock and to learn more about its extent and generative potential.

The work on source rocks in East Greenland is of a very different nature and has a different aim. In Jameson Land in East Greenland good oil source rocks and also good reservoir rocks are well documented due to excellent outcrops (Christiansen et al., 1992). The main source rock levels are Upper Permian (marine Type II source rocks), lowermost Jurassic (lacustrine Type I-II source rocks) and Upper Jurassic (marine Type II source rocks). Here the objective is to take advantage of the excellent exposures of the source and reservoir rocks and intercalated sediments to learn more about the factors which govern their deposition, and in particular, by applying sequence-stratigraphic analysis, to study the role of sea-level changes in relation to other factors in determining both the vertical and lateral distribution of these rocks (Piasecki et al., this report). Since sequence-stratigraphical methods can be used in both outcropping sections and in interpreting seismic sections, it is hoped that the results of this project will improve predictability of the presence of oil source rocks and reservoir lithologies from seismic data both offshore East Greenland and in other parts of the North Atlantic region and northern North Sea. The project is being carried out in cooperation with the Geological Institute of the University of Copenhagen, with support from the Ministry of Energy's Energy Research Programme, and will continue in 1994-95. The 1993 field party consisted of seven geoscientists (sedimentologists and palynologists) and a drilling team. Drilling was carried out using GGU's helicopter-transportable rig, and was concentrated in the Upper Permian and Upper Jurassic sections. A cumulative total of $932 \mathrm{~m}$ core was recovered from the 11 holes completed (Piasecki et al., this report).

The third area of oil-geological activity in Greenland in 1993 was North-East Greenland. Here the first steps were taken in a basin-modelling project which is designed to unravel and as far as possible to quantify the complex thermal history and history of subsidence and uplift in the region since the Cambrian, with particular emphasis on the post-Carboniferous history. An understanding of this development is one of the prerequisites for the evaluation of the prospectivity of the northern part of the North-East 


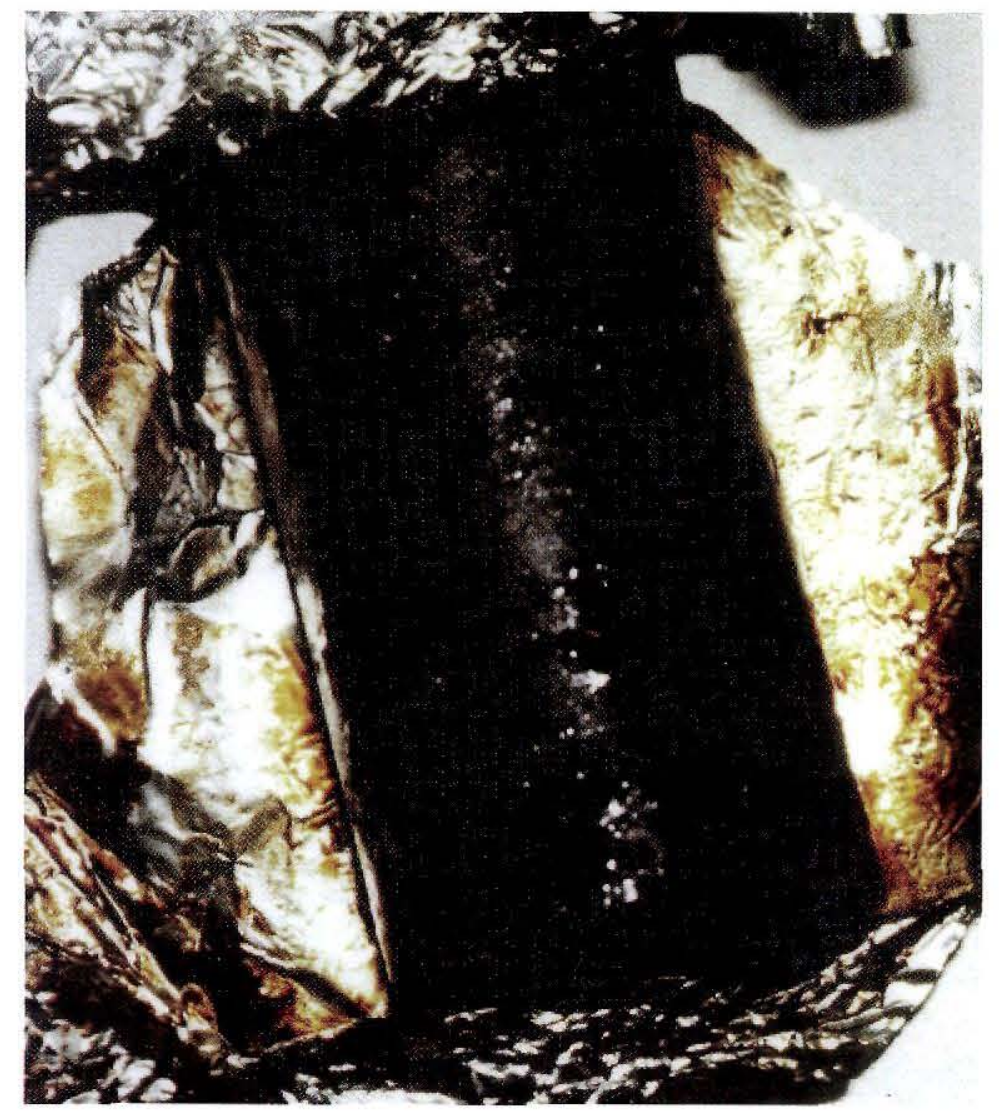

Fig. 1. Core of vesicular basalt with sil-filled vesicles. Oil seeped out and soiled the aluminium foil after the core had been taken into warm, indoor surroundings.

Greenland continental shelf, an area in which seismic data are being acquired as part of the KANUMAS project. The work will be integrated with the regional mapping of the onshore area (Henriksen, this report), and special attention will be given to thermal maturity of source rocks of Early Middle Cambrian and Early Silurian age, and of material from the Carboniferous - Tertiary succession, using both geochemical and physical characters to characterise the state of maturity of these rocks. The uplift history will be further constrained by means of apatite fission track analysis. The Carboniferous - Tertiary succession and the hiati within it will be dated as accurately as possible by biostratigraphical means, in particular by fusulinids and palynomorphs. One possibility that the modelling will test is whether the maturity history of the Upper Palaeozoic source rocks could have allowed these to source an oil field in the shelf area. Work was carried out in 1993 by a single team and was concentrated on the mid-Carboniferous Early Permian carbonates in Amdrup Land (Stemmerik \& Elvebakk, in press).

As already mentioned, no seismic acquisition was carried out in Greenland either by GGU or by the group of companies partaking in the KANUMAS project. The KANUMAS project is a seismic reconnaissance of the North-East
Greenland and North-West Greenland (Melville Bugt) shelves financed by six major oil companies and operated by Nunaoil A/S. The vessel used is the Danish Navy high ice-class fisheries inspection vessel Thetis which has been adapted to accommodate seismic equipment. For the first two seasons of the KANUMAS project the seismic equipment and crew were chartered from a seismic contractor, but in 1993 it was decided that the programme should be suspended to allow Nunaoil to obtain its own seismic equipment in order to reduce its dependence on contractors, funding being provided by the Danish State. This decision had nothing to do with dissatisfaction with the previous arrangement, but is the result of the increased need for flexibility now that the KANUMAS programme in Melville Bugt has been completed and all remaining activity will be off North-East Greenland. Here ice conditions are unpredictable and often severe, and may force last-minute cancellation of an acquisition cruise, something which is not popular with contractors and can be costly. Nunaoil has now completed negotiations for the purchase of its own equipment which will be technically fully up-to-date and suitable for 2-D surveys in any part of the world. A resumption of the KANUMAS programme off North-East Greenland is planned for 1994. 


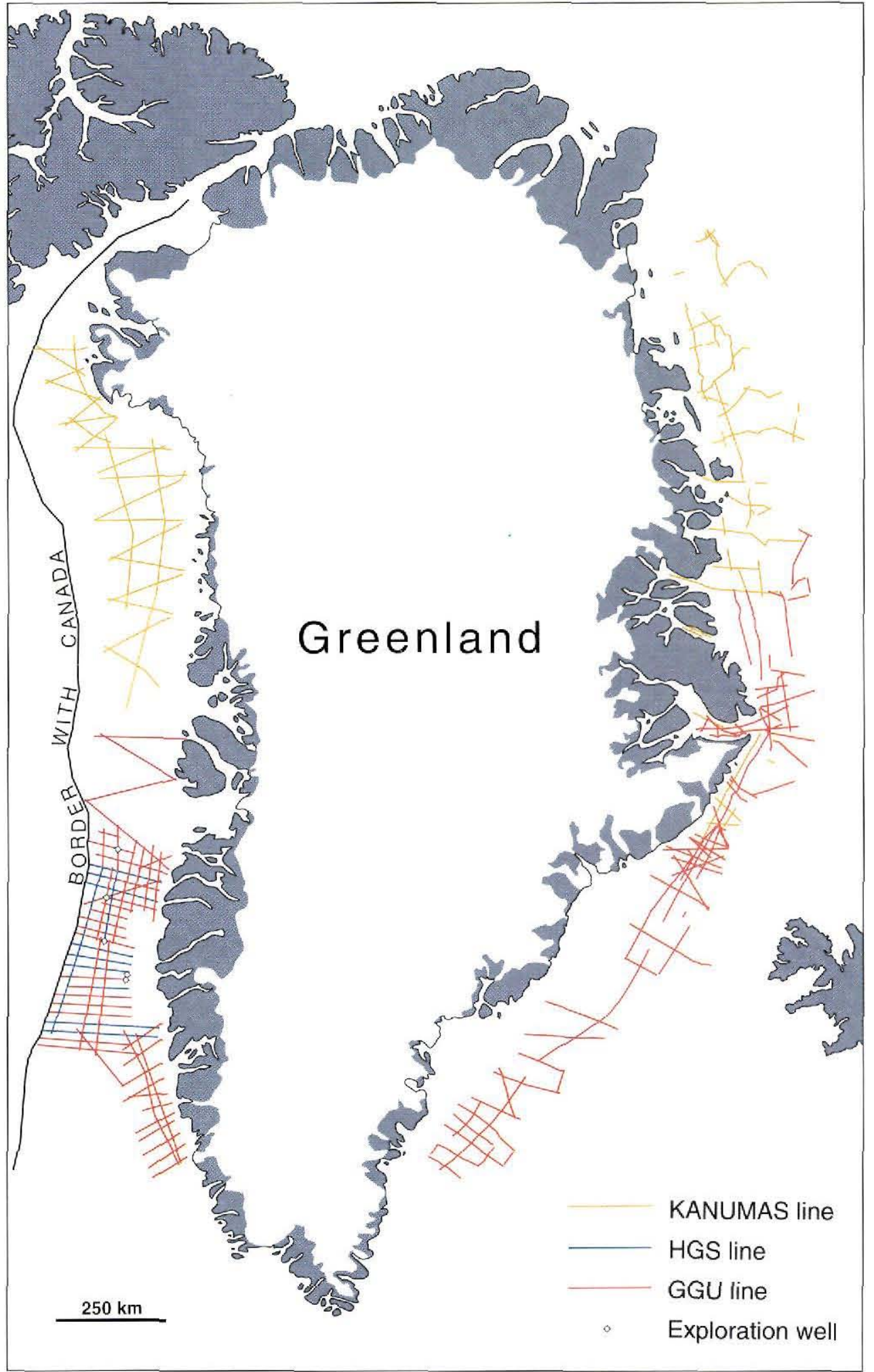

Fig. 2. Map showing the position of all seismic lines acquired by GGU, Nunaoil A/S (KANUMAS project) and Halliburton Geophysical Services Inc. (HGS) since 1980, and the offshore wells of the 1970s. 


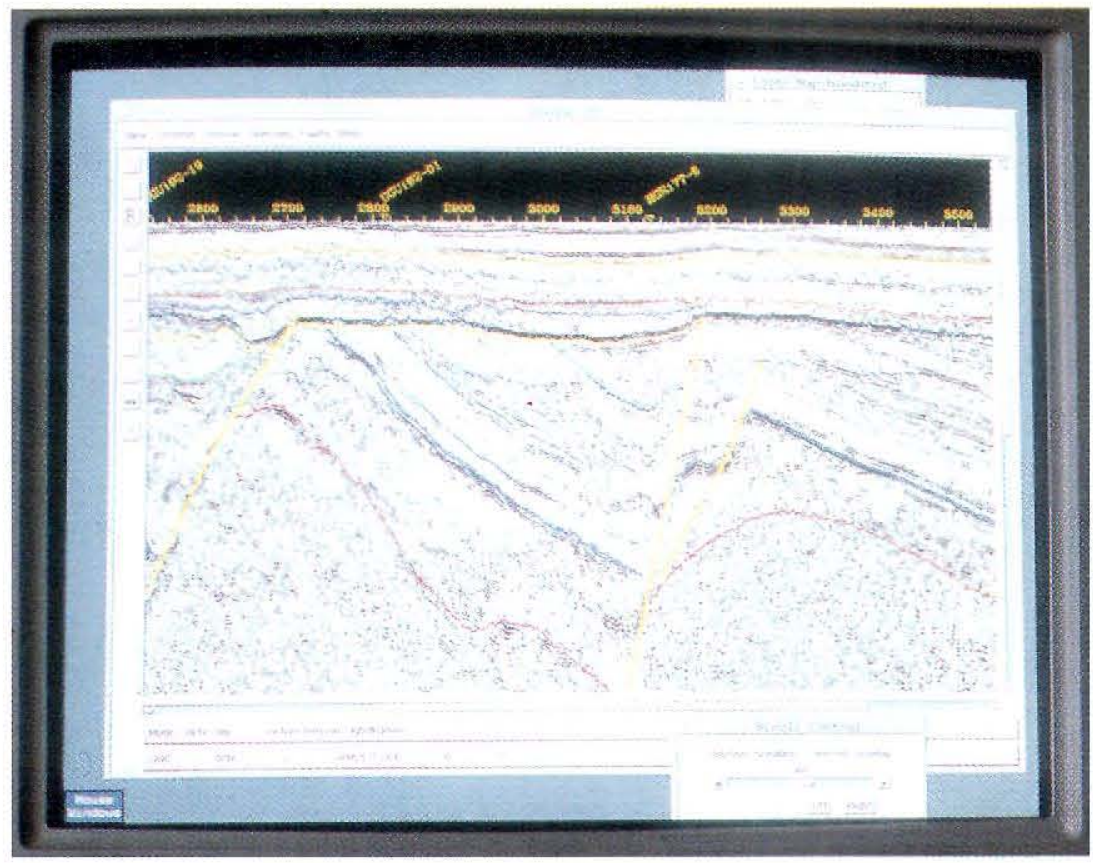

Fig. 3. Part of seismic line offshore southern West Greenland, redisplayed on Landmark work station.

The pause in seismic acquisition offshore Greenland has allowed GGU to concentrate on interpretation and to improve interpretation facilities at the Survey by installing Landmark 2-D interactive work stations. All data acquired by GGU and Nunaoil since 1980 (Fig. 2) have now been loaded onto Landmark, and interpretation of all new data from West Greenland is under way (Fig. 3). In order to homogenise the interpretation, data acquired in southern West Greenland in 1990 and 1991 which had already been preliminarily interpreted on paper are included in the data now being interpreted on Landmark. The interpretation on Landmark has largely confirmed the geological history of the area summarised in Chalmers et al. (1993), but interpretation of 1992 data has allowed a new basin to be mapped near the border to Canadian waters and has also revealed compressional structures in the Davis Strait area. These structures are believed to be the result of transpression associated with a NNE-SSW transform zone which transferred sea-floor spreading movements from the Labrador Sea to Baffin Bay during the Early Tertiary.

Although there was no exploration-related seismic acquisition off Greenland in 1993, seismic acquisition of a different nature took place off South-East Greenland. Here a high-resolution shallow seismic site survey was carried out in preparation for continued ODP (Ocean Drilling Program) drilling in this area. In 1993 the first ODP leg off South-East Greenland was successfully completed with drilling at three sites around which site surveys had been carried out in 1992. The wells reached depths of 875 m. $1320 \mathrm{~m}$ and $147 \mathrm{~m}$ below seabed respectively (Larsen ef al., this report). GGU personnel took part in both the drilling programme and the site survey.

In 1993 the accumulated results of several expeditions and seismic interpretation projects were finally published, both in memoirs and in review articles. These publications form an important part of the background for current assessment of the petroleum potential of some of the main sedimentary basins onshore and offshore Greenland. The most important of these publications are the following:

\section{Offshore West Greenland:}

Exploration history: Chalmers \& Pulvertaft (1993).

Basin development: Chalmers et al. (1993).

\section{Onshore East and North-East Greenland:}

Upper Proterozoic lithostratigraphy: Sønderholm \& Tirsgaard (1993).

Devonian sedimentology and lithostratigraphy: Olsen (1993), Olsen \& Larsen (1993).

Palaeozoic plays: Christiansen et al. (1993a).

Permian source rocks: Christiansen et al. (1993b).

Upper Triassic - Lower Jurassic sequence stratigraphy:

Dam \& Surlyk (1993).

Cretaceous biostratigraphy: Nøhr-Hansen (1993b).

Basin development and exploration potential: Stemmerik et al. (1993). 


\section{References}

Chalmers, J. A. \& Pulvertaft, T. C. R. 1993: The southern West Greenland continental shelf - was petroleum exploration abandoned prematurely? In Vorren, T. O. et al. (ed.) Arctic geology and petroleum potential. Spec. Publ. Norwegian Petrol. Soc. 2 , 55-66. Amsterdam: Elsevier.

Chalmers, J. A., Pulvertaft, T. C. R., Christiansen, F. G., Larsen, H. C., Laursen, K. H. \& Ottesen, T. G. 1993: The southern West Greenland continental margin: rifting history, basin development and petroleum potential. In Parker, J. R. (ed.) Petroleum geology of Northwest Europe: Proceedings of the 4th conference, 915-931. London: Geological Society.

Christiansen, F. G., Dam, G., Piasecki, S. \& Stemmerik, L. 1992: A review of upper Palaeozoic and Mesozoic source rocks from onshore East Greenland. In Spencer, A. M. (ed.) Generation, accumulation, and production of Europe's hydrocarbons II. Spec. Publ. Europ. Ass. Petrol. Geosci. 2, 151-161. Berlin: Springer-Verlag.

Christiansen, F. G., Larsen, H. C., Marcussen, C., Piasecki, S. \& Stemmerik, L. 1993a: Late Paleozoic plays in East Greenland. In Parker, J. R. (ed.) Petroleum geology of Northwest Europe: Proceedings of the 4th conference, 657-666. London: Geological Society.

Christiansen, F. G., Piasecki, S., Stemmerik, L. \& Telnæs, N. 1993b: Depositional environment and organic geochemistry of the Upper Permian Ravnefjeld Formation source rocks in East Greenland. Bull. Amer. Ass. Petrol. Geol. 77, 1519-1537.

Dam, G. \& Surlyk, F. 1993: Cyclic sedimentation in a large waveand storm-dominated anoxic lake; Kap Stewart Formation (Rhaetian-Sinemurian), Jameson Land, East Greenland. In Posamentier, H. W, et al. (ed.) Sequence stratigraphy and facies associations. Int. Ass. Sediment. Spec. Publ. 18, 419-448.
Dam, G. \& Sønderholm, M. in press: Lowstand slope channels of the Itilli succession (Maastrichtian-Lower Paleocene), Nuussuaq, West Greenland. Submitted to Sed. Geol.

Nøhr-Hansen, H. 1993a: Upper Maastrichtian? - lower Paleocene dinoflagellate cysts and pollen from turbidites in the Itilli region, Nuussuaq, central West Greenland - first dating of the sediments. Rapp. Gronlands geol. Unders. 159, 81-87.

Nøhr-Hansen, H. 1993b: Dinoflagellate cyst stratigraphy of the Barremian to Albian, Lower Cretaceous, North-East Greenland. Bull. Grønlands geol. Unders. 166, $171 \mathrm{pp}$.

Olsen, H. 1993: Sedimentary basin analysis of the continental Devonian basin in North-East Greenland. Bull. Gronlands geol. Unders. 168, $80 \mathrm{pp}$.

Olsen, H. \& Larsen, P.-H. 1993: Lithostratigraphy of the continental Devonian sediments in North-East Greenland. Bull. Gronlands geol. Unders. 165, $108 \mathrm{pp}$.

Stemmerik, L. \& Elvebakk, G. in press: A newly discovered midCarboniferous - ?early Permian reef complex in the Wandel Sea Basin, eastern North Greenland. Rapp. Gronlands geol. Unders.

Stemmerik, L., Christiansen, F. G., Piasecki, S., Jordt, B., Marcussen, C. \& Nøhr-Hansen, H. 1993: Depositional history and petroleum geology of the Carboniferous to Cretaceous sediments in the northern part of East Greenland. In Vorren, T. O. et al. (ed.) Arctic geology and petroleum potential. Spec. Publ. Norwegian Petrol. Soc. 2, 67-87. Amsterdam: Elsevier.

Sønderholm, M. \& Tirsgaard, H. 1993: Lithostratigraphic framework of the Upper Proterozoic Eleonore Bay Supergroup of East and North-East Greenland. Bull. Gronlands geol. Unders. $167,38 \mathrm{pp}$.

F. G. C. \& T. C. R. P., Geological Survey of Greenland, Copenhagen 